九州大学学術情報リポジトリ

Kyushu University Institutional Repository

\title{
Changes in Soluble and Membrane Proteins of Chlorella ellipsoidea during Early Time of Hardening
}

Yoshimoto, Makoto

Laboratory of Food Hygienic Chemistry, Faculty of Agriculture, Kyushu University

Okamura, Hideki

Laboratory of Food Hygienic Chemistry, Faculty of Agriculture, Kyushu University

Joh, Toshio

Laboratory of Food Hygienic Chemistry, Faculty of Agriculture, Kyushu University

Mi yamoto, Takah isa

Laboratory of Food Hygienic Chemistry, Faculty of Agriculture, Kyushu University

他

https://doi.org/10.5109/23970

出版情報: 九州大学大学院農学研究院紀要. 36 (1/2)，pp.69-77，1991-10. Kyushu University バージョン：

権利関係 : 


\title{
Changes in Soluble and Membrane Proteins of Chlorella ellipsoidea during Early Time of Hardening
}

\author{
Makoto Yoshimoto, Hideki Okamura, Toshio Joh, \\ Takahisa Miyamoto and Shoji Hatano \\ Laboratory of Food Hygienic Chemistry, Faculty of Agriculture, \\ Kyushu University 46-09, Fukuoka 812, Japan
}

(Received July 8, 1991)

\begin{abstract}
Soluble and membrane proteins from Chlorella ellipsoidea Gerneck (IAM C-27) during the early time of hardening were separated by two-dimensional gel electrophoresis and visualized by silver staining. The analysis of soluble protein showed that 14 polypeptides newly appeared and 3 polypeptides increased in abundance within $24 \mathrm{~h}$ of cold treatment. Three polypeptides having the molecular weight $80 \mathrm{kDa}(\mathrm{pI} 5.58), 82 \mathrm{kDa}$ (pI 5.46) and 66 $\mathrm{kDa}(\mathrm{pI} 6.11)$ were detected after a 6 -h or a 9-h hardening and markedly increased as the time of hardening proceeded. The result suggests that they may play an important role for the development of cold hardiness. One small polypeptide $(29.8 \mathrm{kDa}, \mathrm{pI} 4.44)$ was detectable in membrane fraction of $12 \mathrm{~h}$-hardened cells. Membrane protein of $29.2 \mathrm{kDa}$ (pI 5.05) was pronounced after a 12-h hardening. Two major groups of membrane polypeptide (50.8-55. $4 \mathrm{kDa}, \mathrm{pI} 5.29-5.76$ and 50.8-55.4 kDa,pI 6.70-7.10) disappeared after a 3-h hardening and were not observed following a longer hardening period, suggesting the rapid degradation of these membrane polypeptides during cold treatment.
\end{abstract}

\section{INTRODUCTION}

Many plants become more resistant to freezing temperature when first exposed to low, nonfreezing temperatures (Graham and Patterson, 198'2). A number of reports have shown physiological and biological changes in plants during cold treatment and it has been suggested that these changes are mediated by altered gene expression (Guy et al., 1985 ; Meza-Basso et al., 1986; Mohapatra et al., 1987 ; Harn and Walbot, 1989). Recently mRNAs, which were induced during cold treatment, were cloned from tomato (Schaffer and Fischer, 1988), alfalfa (Mohapatra et al., 1989), and barley (Cattivelli and Bartels, 1990). However, the function and the cellular localization of the proteins encoded by the cloned mRNAs are unknown. The isolation and characterization of genes associated with the development of frost hardiness is important to clarify the regulation of the mechanism. On the other hand, the purification and characterization of proteins associated with the development and maintenance of frost hardiness help to understand their roles and functions during hardening.

We have used Chlorella ellipsoidea Gerneck (IAM C-27) for studying on freezing tolerance. Chlorella species are suitable for cold-hardiness research : The synchronized cells are uniform and the cell cycle is much shorter than higher plants. In addition, a broad cold tolerance spectrum is available in Chlorella species. Our previous papers have demonstrated that RNA and protein syntheses and lipid changes are involved in the hardening process (Hatano, 1978 ; Hatano, et al., 1981). These results suggest that 
Chlorella cells can respond to hardening by inducing the synthesis of specific proteins. It is not yet understood what kind of protein is responsible for triggering induction of frost hardiness. We have planned to separate systematically the soluble or membrane proteins from Chlorella cells during early phase of hardening and to identify the proteins which involve the initiation and development of frost hardiness. It is requested to know changes in soluble or membrane proteins during hardening by twodimensional electrophoresis before the systematic separation of their proteins.

We report data that the pattern of soluble or membrane proteins in Chlorella ellipsoidea Gerneck (IAM C-27) is changed during early phase of hardening.

\section{MATERIALS AND METHODS}

\section{Plant material}

Chlorella ellipsoidea Gerneck (IAM C-27) was synchronously grown in the MC medium of Watanabe (1960). Thus, the cells were cultured at $25^{\circ} \mathrm{C}$, under 9 to 10 kilolux, with $1.3 \% \mathrm{CO}_{2}$-air, at a concentration of about $5 \times 10^{9}$ cells/ 1 to $15 \times 10^{9}$ cells/ 1 and 16-h light/8-h dark regime. As the cells were hardened most at the $\mathrm{L}_{2}$ stage (an intermediate stage in the ripening phase of the cell cycle), $L_{2}$ cells were used for this experiment. Cold treatment at $3^{\circ} \mathrm{C}$ was carried out as described for the time periods mentioned in the text or figure legends.

Tests of frost hardiness were carried out as described previously (Hatano et al., 1982).

\section{Protein extraction}

The Chlorella samples were removed from $-80^{\circ} \mathrm{C}$ storage, and suspended in 100 $\mathrm{mM}$ potassium phosphate $(\mathrm{pH} 7.5), 1 \mathrm{mM}$ EDTA, and $1 \mathrm{mM}$ PMSF and disrupted at $0^{\circ} \mathrm{C}$ in a Vibrogen-Zellmühle. The homogenate was filtered through a glass funnel. The filtrate was centrifuged at $13,800 \mathrm{Xg}$ for $20 \mathrm{~min}$ and the cell debris was removed by the centrifugation. Some of the supernatants were dialyzed against deionized water and lyophilized for SDS-polyacrylamide gel electrophoresis. The remaining supernatant was recentrifuged at $165,000 \mathrm{Xg}$ for $90 \mathrm{~min}$. The supernatant obtained was used as the soluble protein fraction and the pellet, which contained mainly microsomes and plasma membranes, was used as the source of membrane proteins. The supernatant was dialyzed against deionized water and lyophilized. Protein was determined by the dye -binding method using bovine serum albumin as a standard (Bradford, 1976).

\section{SDS-polyacrylamide gel electrophoresis and two-dimensional gel electrophoresis}

SDS-polyacrylamide gel electrophoresis (SDS-PAGE) was carried out as a Laemmli's method (1970). The samples were dissolved in Laemmli sample solubilizing buffer (62.5 mM Tris-HCI, pH 6.8, 10\% glycerol, 2\% SDS, 5\% 2-mercaptoethanol). The each protein sample (30 $\mu \mathrm{g}$ of protein) from $13,800 \mathrm{Xg}$ supernatant was analyzed in 10 $\%$ polyactrylamide gel containing $0.1 \%$ SDS utilizing a $12 \mathrm{~cm}$ separating gel.

For two-dimensional gel electrophoresis, a O'Farrell system (1975) was used. The lyophilized soluble protein and membranes were solubilized in a lysis buffer containing $9 \mathrm{M}$ urea, 3\% Nonidet P-40 and 2\% Ampholine ( $\mathrm{pH} 3.5-10)$. Isoelectric focusing was 
performed in g-cm-long, 1.5 -mm-diameter rod gels using $4.2 \%$ polyacrylamide containing $9 \mathrm{M}$ urea, 3\% Nonidet P-40, and 2\% Ampholine (pH3.5-10). The isoelectric focusing was run for $4,550 \mathrm{~V} \cdot \mathrm{h}$. The samples $(60 \mu \mathrm{g}$ protein) were loaded on the gels. After migration, the gels were equilibrated in second dimension sample buffer (62.5 mM Tris-HCI, pH 6.8, 10\% glycerol, 2\% SDS, 5\% 2-mercaptoethanol) and loaded onto SDS-PAGE (10\%) gels utilizing a $6 \mathrm{~cm}$ separating gel. The gels were fixed and silverstained (Oakley et al., 1980).

\section{RESULTS}

\section{SDS-PAGE of crude extract proteins during hardening}

Changes in protein patterns of the crude extract during hardening was monitored with SDS-PAGE (Fig. 1). Between 9 and $24 \mathrm{~h}$ after beginning of the cold treatment, the polypeptide having molecular weight about $80 \mathrm{kDa}$ markedly increased. However, the resolution of the gels was not good enough to determine how many polypeptides were affected.

\section{Changes in soluble protein patterns during hardening}

The samples were compared using a two-dimensional gel electrophoresis system. Changes in the soluble protein population are shown in Fig. 2. About 280 polypeptide spots could be resolved in this system.

Many polypeptides appeared and disappeared during hardening. Since cold tolerance is closely related with induction of specific proteins during cold treatment (Guy

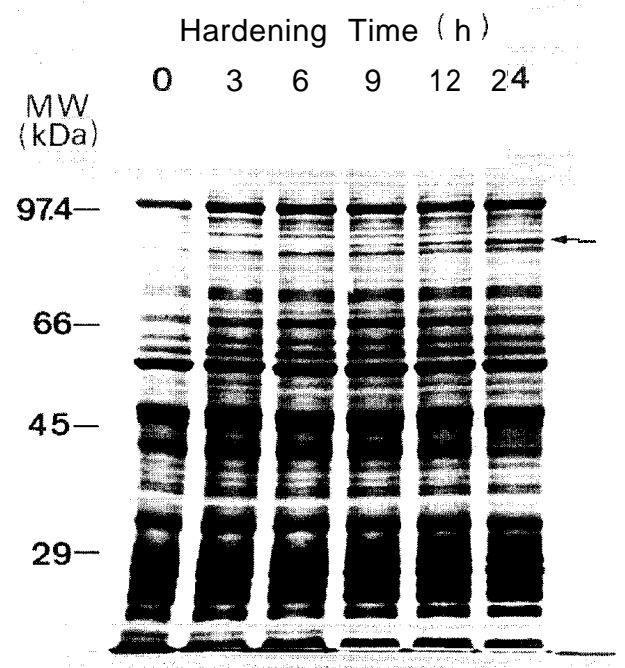

Fig. 1. SDS-PAGE of crude extract proteins from Chlorella ellipsoidea during hardening. Changing band is indicated by arrow on the right side of the electrophoregraph. Numbers in the left margin indicate molecular weight of the maker proteins. 


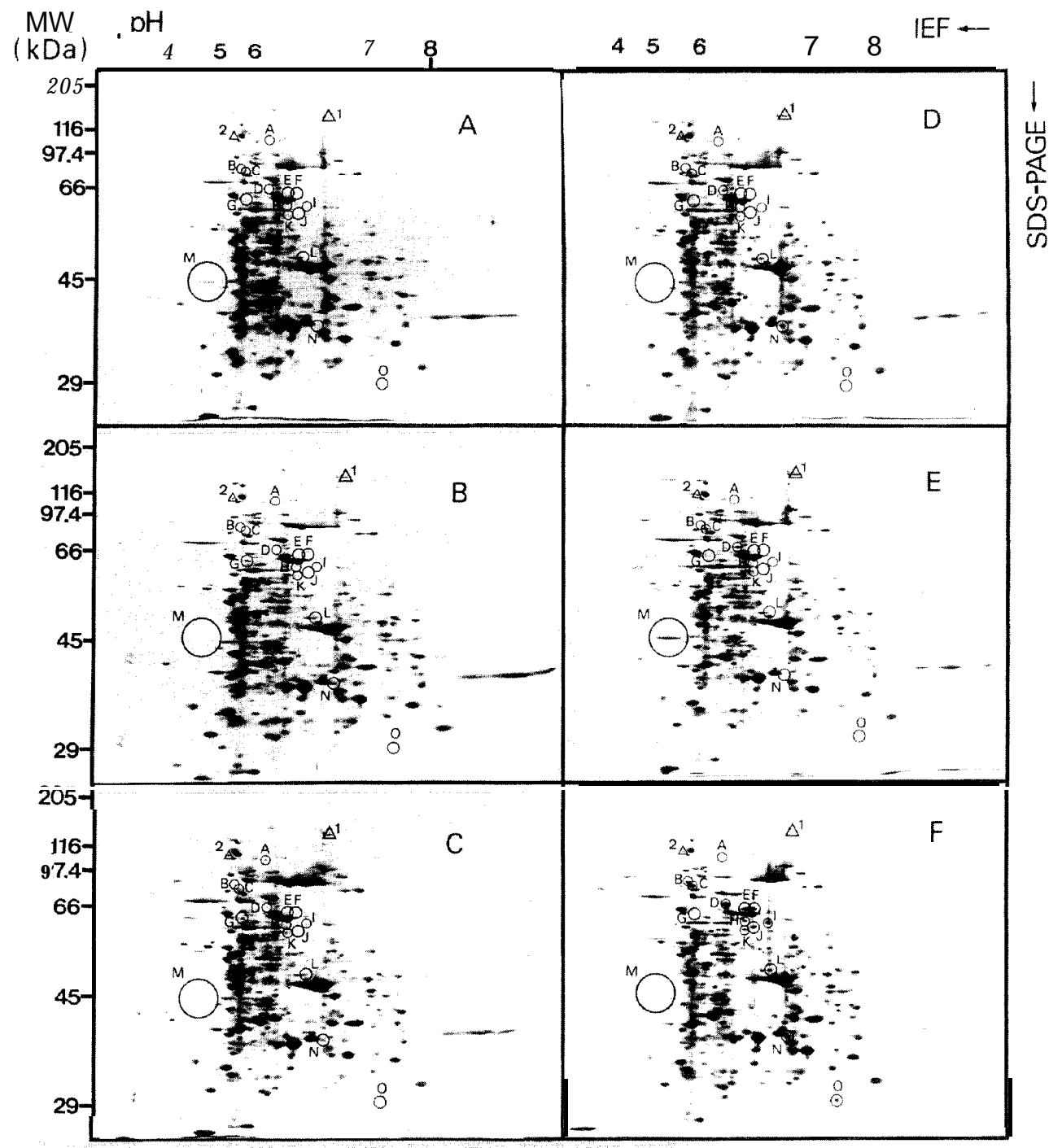

Fig. 2. Two-dimensional electrophoresis of soluble proteins extracted from cold-treated Chlorella ellipsoidea cells. Hardening time : A, 0 h; B, 3 h; C, 6 h ; $\mathrm{D}, 9 \mathrm{~h} ; \mathrm{E}, 12 \mathrm{~h} ; \mathrm{F}, 24 \mathrm{~h}$. Circles and triangles indicate polypeptides which newly appeared or increased respectively during hardening. 
and Haskell, 1987), we did not summarize the soluble proteins in this report which disappeared during hardening. A summary of the relative molecular weight masses and isoelectric points of the proteins that newly appeared and increased in abundance is given in Table 1. Spots alphabeted A to $\mathrm{N}$ (open circles) are undetectable on the gel of unhardened sample and indicate polypeptides newly appeared after a temperature shift. The relative intensity of spots numbered 1 to 3 (open triangles) increased after a cold treatment and these spots were observed on the control gel (hardening $0 \mathrm{~h}$ ). A majority of the spots from hardened samples were common to proteins isolated from unhardened sample. Seventeen soluble polypeptides newly appeared or increased during a 24-h hardening. Of these, two polypeptides (spots G [63 kDa, pI 5.751; M [38 $\mathrm{kDa}$, pI 6.591) newly appeared after a 3-h hardening. The polypeptide of $63 \mathrm{kDa}(\mathrm{pI}$ 5.75) was not observed after a 9-h hardening. Two high molecular weight polypeptides (spots A [106 kDa,pI 6.071 ; C [80 kDa,pI 5.581) were detectable in the sample of a 6 $-\mathrm{h}$ hardening and consistently induced following a longer hardening period. The 80 $\mathrm{kDa}$ polypeptide indicated the marked increase following cold treatment. Two proteins (spots B [82 kDa,pI 5.461; D [66 kDa, pI 6.111) appeared after a 9-h hardening and the abundance increased following a longer hardening period. Especially the intensity of the $82 \mathrm{kDa}$ polypeptide was pronounced after a 24-h hardening. Eight polypeptides (spots E [64 kDa,pI 6.351; F[64 kDa, pI 6.301; H [61 kDa, pI 6.301; I [61 kD,pI 6.441; J [60 kDa, pI 6.371; K [59 kDa, pI 6.301; L [50 kDa, pI 6.481; N [27 kDa, pI 7.131) were detectable only in 24-h hardened sample. Of these, seven polypeptides except for the one of $27 \mathrm{kDa}$ (pI 7.13) had the molecular weights ranging from 50 to 64 $\mathrm{kDa}$ and isoelectric points ranging from 6.30 to 6.48. Abundance of two high molecular weight polypeptides (spots $1[141 \mathrm{kDa}, \mathrm{pI} 6.671 ; 2[110 \mathrm{kDa}, \mathrm{pI} 5.421$ ) increased after temperature shift. However, the abundance of these two polypeptides after a 24-h hardening was depressed at the level of unhardened sample. The polypeptide of $45 \mathrm{kDa}$

Table 1. Changes in soluble proteins during hardening

\begin{tabular}{|c|c|c|c|c|c|c|c|}
\hline \multirow[b]{2}{*}{ spot } & \multirow[b]{2}{*}{ MW (kDa) } & \multirow[b]{2}{*}{$\mathrm{pI}$} & \multicolumn{5}{|c|}{ Hardening time $(\mathrm{h})$} \\
\hline & & & 3 & 6 & 9 & 12 & 24 \\
\hline A & 106 & 6.07 & & & & & \\
\hline $\mathrm{B}$ & 82 & 5.46 & & & & $\mathrm{i}$ & \\
\hline $\mathrm{C}$ & 80 & 5.58 & & $\mathrm{i}$ & & $\mathrm{i}$ & $\mathrm{i}$ \\
\hline $\mathrm{D}$ & 66 & 6.11 & & & $\mathrm{i}$ & & $\mathrm{i}$ \\
\hline $\mathrm{E}$ & 64 & 6.35 & & & & & \\
\hline $\mathrm{F}$ & 64 & 6.30 & & & & & \\
\hline $\mathrm{G}$ & 63 & 5.75 & & $\mathrm{i}$ & & & \\
\hline $\mathrm{H}$ & 61 & 6.30 & & & & & $\mathrm{i}$ \\
\hline I & 61 & 6.44 & & & & & $\mathrm{i}$ \\
\hline $\mathrm{J}$ & 60 & 6.37 & & & & & $\mathrm{i}$ \\
\hline $\mathrm{K}$ & 59 & 6.30 & & & & & $\mathrm{i}$ \\
\hline $\mathrm{L}$ & 50 & 6.48 & & & & & \\
\hline M & 38 & 6.59 & & & $\mathrm{i}$ & & \\
\hline $\mathrm{N}$ & 27 & 7.13 & & & & & \\
\hline 1 & 141 & 6.67 & + & & + & & \\
\hline 2 & 110 & 5.42 & 1 & & & & \\
\hline 3 & 45 & 4.82 & & & & & \\
\hline
\end{tabular}

i, induced ; + , increased. 
(spot 3, pI 4.82) temporarily increased after a 12-h hardening.

\section{Changes in membrane protein during hardening}

Changes in the membrane protein population are shown in Fig. 3. A summary of the relative molecular weight masses and isoelectric points of the proteins that changed in abundance is given in Table 2. The analysis of membrane polypeptide patterns revealed the remarkable appearance of ' $29.8 \mathrm{kDa}(\mathrm{pI} 4.44)$ after a 12-h hardening. Abundance of $29.2 \mathrm{kDa}$ polypeptide (pI 5.05) increased after $12 \mathrm{~h}$ of cold treatment and the accumulation of this polypeptide was more pronounced following a longer hardening period. Both groups of major polypeptides (spots I [50.8-55.4 kDa, pI 5.29-5.76]; II [50.8-55.4 kDa, pI 6.70-7.10]) disappeared after a 3-h hardening and were no longer observed following prolonged treatment.

\section{DISCUSSION}

Some reports have shown that Coomassie blue staining of the total proteins extracted from various plants can not detect differences in protein profiles or their relative proportions during the induction of frost hardiness (Johnson-Flanagan and Singh, 1987 ; Cloutier, 1983). Therefore, the silver-staining method was employed in this experiment. In two-dimensional gel electrophoresis, about 280 polypeptides in the soluble fractions were resolved.

We found that, upon exposure to hardening conditions, 14 polypeptides were novel and 3 ones increased in abundance. Of these, five polypeptides having the molecular weight, 106, 82, 80, 63 and $38 \mathrm{kDa}$ were newly induced and $141 \mathrm{kDa}$ and $110 \mathrm{kDa}$ polypeptides increased in abundance between $3 \mathrm{~h}$ and $9 \mathrm{~h}$ of hardening. The polypeptide $(80 \mathrm{kDa}, \mathrm{pI} 5.58)$ agreed at the molecular weight and appearance time with the one which markedly increased in SDS-PAGE (Fig. 1). The rapid response of their polypeptides to hardening suggests that they may play an important role for the initiation or the development of frost hardiness.

Induction of high molecular weight polypeptides having 160,117 , and $85 \mathrm{kDa}$ in spinach (Guy and Haskell, 1987), $160 \mathrm{kDa}$ (pI 4.5) in Arabidopsis thatiana (Gilmour et al., 1988), $200 \mathrm{kDa}$ (pI 6.85) in wheat (Perras and Sarhan, 1989) have been reported. Five polypeptides (mol wt, 141, 110, 106, 82, and $80 \mathrm{kDa}$ ) of 7 polypeptides newly induced or increased during hardening of Chlorella ellipsoidea. It is difficult to say whether the mechanism that induces frost hardiness in higher plants and Chlorella cell is similar. The cloning of the induced genes is needed to determine the molecular homology of the proteins induced in various kind of plants or Chlorella ellipsoidea during cold treatment.

Sadakane et al. (1980) have reported that glucose 6-phosphate dehydrogenase in Chlorella ellipsoidea $\mathrm{C}-27$ is highly activated during the early phase of hardening by only low temperature. Recently we have purified dithiothreitol-sensitive glucose 6phosphate dehydrogenase (55 kDa,pI 5.0 in the two-dimensional electrophoresis) coming from chloroplast (not shown). However, we could not indicate the participation of the enzyme here. This may be due to the sensitivity of the visualization of the spot in the electrophoresed gel.

In membrane fraction, two major membrane polypeptides having molecular 


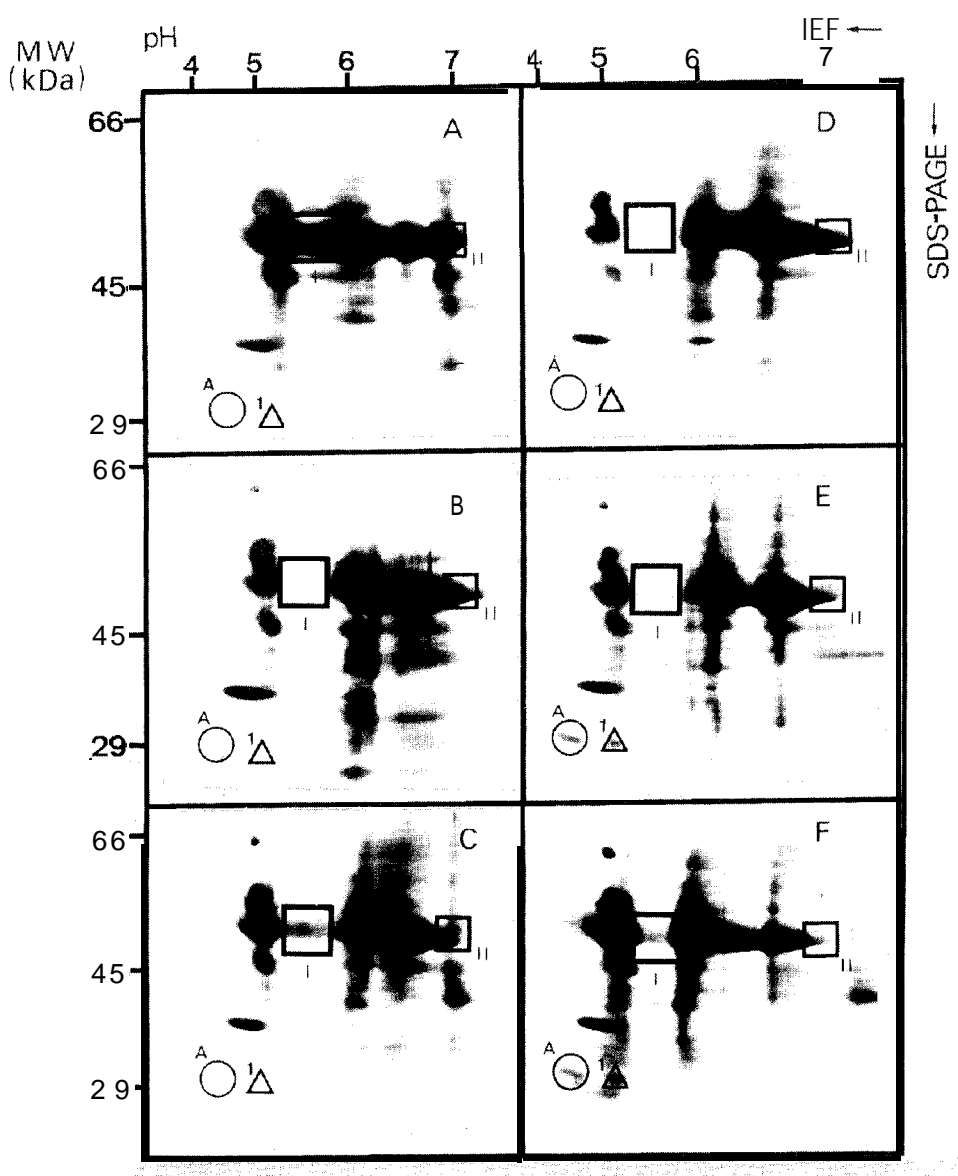

Fig. 3. Two-dimensional electrophoresis of membrane proteins from Chlorella ellipsoidea during hardening. Hardening time: A, 0 h; B, $3 \mathrm{~h} ; \mathrm{C}, 6 \mathrm{~h} ; \mathrm{D}, 9 \mathrm{~h}$; E, $12 \mathrm{~h} ; \mathrm{F}, 24 \mathrm{~h}$. Circles and triangles indicate polypeptides which newly appeared or increased respectively during hardening while boxes indicate polypeptides which decreased during hardening.

Table 2. Changes in membrane proteins during hardening

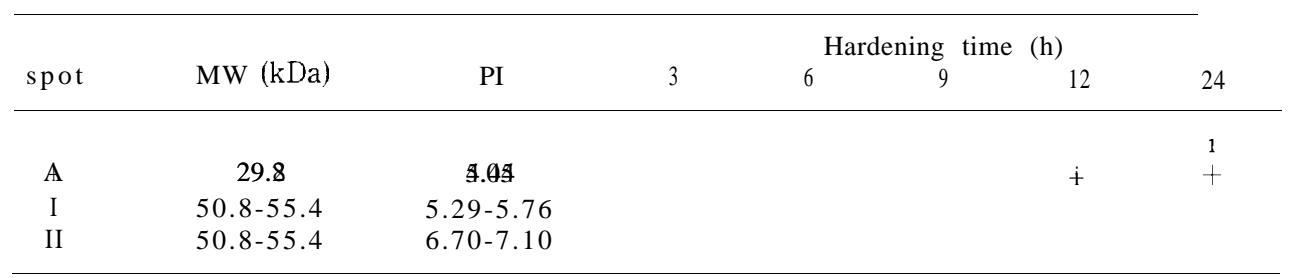

$\mathrm{i}$, induced $;+$, increased $;-$, decreased. 
weight of about 50 to $55 \mathrm{kDa}$ decreased rapidly during hardening, suggesting the degradation of membrane proteins. Steponkus (1984) has reported that plasma membranes are primary site of freezing injury. Shih et al. (1967) have also indicated a positive correlation between membrane protein content and cold hardiness. In spite of the disappearance of both membrane polypeptides, the Chlorella cell can maintain and develop frost hardinesss. It is possible that newly induced protein may substitute for the disappeared membrane proteins. That is to say, part of frost hardiness in Chlorella cells may involve the reorganization membrane proteins by both suppression and induction of specific proteins, resulting in the stabilization of the membrane against low temperature. Mohapatra et al. (1988) have demonstrated that cold acclimation induces two membrane polypeptides in alfalfa seedling membrane. Further experiments are required to clarify the possibility.

In conclusion, the rapid development of frost hardiness in Chlorella ellipsoidea was paralleled by changes in soluble and membrane proteins. The appearance of some novel proteins suggests the correlation with frost hardiness. However, the function or the participation of these proteins in the frost hardiness is obscure. Experiments are in progress to separate systematically the proteins induced during early phase of hardening by high performance liquid chromatography. These fractionated proteins will be identified to elucidate the physiological role of the proteins in the induction of cold hardiness in Chlorella ellipsoidea. The data concerning the de novo synthesis of the novel proteins induced during the early phase of hardening will be reported in the near future.

\section{REFERENCES}

Bradford, M. M. 1976 A rapid and sensitive method for the quantitation of microgram quantities of protein utilizing the principle of protein-dye binding. Anal. Biochem., $72: \mathbf{2 4 8 - 2 5 4}$

Cattivelli, L. and Bartels, D. 1990 Molecular cloning and characterization of cold-regulated genes in barley. Plant Physiol., 93 :1504-1510

Cloutier, Y. 1983 Changes in the electrophoretic patterns of the soluble proteins of winter wheat and rye following cold acclimation and dedication stress. Plant Physiol., 71: 400-403

Gilmour, S. J., Hajela, R. K. and Thomashow, M. F. 1988 Cold acclimation in Arabidopsis thaliana. Plant Physiol., 87 : 745-750

Graham, D. and Patterson, B. D. 1982 Responses of plans to low, nonfreezing temperatures : Proteins, metabolism, and acclimation. Annu. Rev. Plant physiol., 33 : 347-372

Guy, C. L., Niemi, K. J. and Brambl, R. 1985 Altered gene expression during cold acclimation of spinach. Proc. Natl. Acad. Sci. USA., 82 : 3673-3677

Guy, C. L. and Haskell, D. 1987 Induction of freezing tolerance in spinach is associated with the synthesis of cold acclimation induced proteins. Plant Physiol., 84 : 872-878

Harn, M. and Walbot, V. 1989 Effects of cold-treatment on protein synthesis and mRNA levels in rice leaves. Plant Physiol., 91 : 930-938

Hatano, S. 1978 Studies on frost hardiness in Chlorella ellipsoidea : Effects of antimetabolites, surfactants, hormones, and sugars on the hardening process in the light and dark. In 'Plant Cold Hardiness and Freezing Stress, Mechanisms and Crop Implications', ed. by P. H. Li and A. Sakai, Academic Press, New York, pp. 175-196

Hatano, S., Kabata, K. and Sadakane, H. 1981 Transition of lipid synthesis from chloroplasts to a cytoplasmic system during hardening in Chlorella ellipsoidea. Plant Physiol., 67 : 216-220

Hatano, S., Kabata, K., Yoshimoto, M. and Sadakane, H. 1982 Accumulation of free fatty acids during 
hardening of Chlorella ellipsoidea. Plant Physiol., 70: 1173-1177

Johnson-Flanagan, A. M. and Singh, J. 1987 Alteration of gene expression during the induction of freezing tolerance in Brassica napus suspension cultures. Plant Physiol., 85 : 699-705

Laemmli, U. K. 1970 Cleavage of structural proteins during the assembly of the head of bacteriophage T4. Nature, $227: 680-685$

Meza-Basso, L., Alberdi, M., Raynal, M., Ferrero-Cadinanos, M. and Delseny, M. 1986 Changes in protein synthesis in rapeseed (Brassica napus) seedlings during a low temperature treatment. Plant Physiol., 82 : 733-738

Mohapatra, S. S., Poole, R. J. and Dhindsa, R. S. 1988 Detection of two memdrane polypeptides induced by abscisic acid and cold acclimation : possible role in freezing tolerance. Plant Cell Physiol., $29: 727-730$

Mohapatra, S. S., Walfraim, L., Poole, R. J. and Dhindsa, R. S. 1989 Molecular cloning and relationship to freezing tolerance of cold-acclimation-specific genes of alfalfa. Plant Physiol., $89: 375-380$

Oakley, B. R., Kirsch, D. R. and Morris, N. R. 1980 A simplified ultrasensitive silver stain for detecting proteins in polyacrylamide gels. Anal. Biochem., $105: 361-365$

O'Farrell, P. H. 1975 High resolution two-dimensional electrophoresis of proteins. J. Biol. Chem., 19 : 4007-4021

Perras, M. and Sarhan, F. 1989 Synthesis of freezing tolerance proteins in leaves, crown, and roots during cold acclimation of wheat. Plant Physiol., $89: 577-585$

Sadakane, H., Kabata, K., Ishibashi, K., Watanabe, T. and Hatano, S. 1980 Studies on frost hardiness in Chlorella ellipsoidea. V. The role of glucose and related compounds. Environ. Exp. Botany, 20 : 297-305

Schaffer, M. A. and Fischer, R. L. 1988 Analysis of mRNAs that accumulate in response to low temperature identifies a thiol protease gene in tomato. Plant Physiol., $87: 431-436$

Shih, S. C., Jung, G. A. and Shelton, D. C. 1967 Effects of temperature and photoperiod on metabolic changes in alfalfa in relation to cold hardiness. Crop Sci., $7: 385^{-389}$

Steponkus, P. L. 1984 Role of the plasma membrane in freezing injury and cold acclimation. Annu. Rev. Plant Physiol., 35 :543-584

Watanabe, A. 1960 List of algal strains in collection at the Institute of Applied Microbiology, University of Tokyo. J. Gen. Appl.Microbiol., 6 : 283-292 